i bogen: bl.a. påpegningen af uligheden mellem de forskellige kommuners mulighed for at kunne investere $\mathrm{i}$ oplevelser som offentligt tiltag, at forskellige diskurser og hegemonier er på færde i strategiudarbejdning, og der er et hensyn til en "grøn økonomi" at tage i den overordnede økonomi. Men selvom man således er på vej til et fokus på, hvordan økonomi og antropologi kan optræde i en normativ planmæssig sammenhæng, så får vi stort set endnu en fortælling om oplevelser som det nye erhvervsmæssige krydderi, men nu tilsat det offentlige også. På trods af intentionen stiller man sig grundlæggende tilfreds med at karakterisere oplevelsesøkonomi som et nyt og mere fantasirigt stadie $i$ den moderne kapitalisme som det hedder (s. 115), og accepterer derfor implicit at det offentlige skal indoptage de samme politiske og økonomiske forudsætninger. Men det er vel egentlig først når spørgsmålet hvorfor slet ikke melder sig, at det bliver rigtig kritisk?
KASPER HEDEGÅR

SCHIØLIN

\section{Prolegomena zu einer jeden künftigen Technikphilosophie}

Soren Riis: Zur Neubestimmung der Technik Eine Auseinandersetzung mit Martin Heidegger, Francke Verlag, 2011 , 304 sider, 439 kr.

Der er endnu ikke mange danske filosoffer og idéhistorikere endsige intellektuelle generelt, der kaster sig over teknologi med samme glubende sult, hvormed de fylder sig med alverdens andre åndelige lækkerier. Men hvorfor egentlig ikke? Måske man frygter at forurene tanken, give den en fæl metallisk bismag? Men teknologi er jo dog en sober - hvis da ikke strengt nødvendig - beskæftigelse for tænkningen. Det siger Heidegger! Han lærer os, at spørgsmålet om teknikken er gennemsyret af metafysik, ontologi, væren og sandhed, hvorfor teknologien uagtet dens ingeniør- og naturvidenskabsagtige skin er en larmende invitation til selv de mest teknikforskrækkede åndsaristokrater. (Teknik og teknologi anvendes her synonymt).

Den danske filosof Søren Riis har lært Heideggers teknologilektie og taget imod teknologiens filosofi- 
ske invitation. Men heldigvis er Riis ikke nogen autoritetstro Heidegger-discipel. Allerede titlen og især undertitlen på hans her anmeldte afhandling emmer af faderopgør: Zur Neubestimmung der Technik. Eine Auseinandersetzung mit Martin Heidegger.

Af mange grunde er Riis' afhandling vigtig og tiltrængt. Måske allermest fordi Heidegger indtager rollen som en slags faderfigur for de nutidige filosoffer, der med dedikerede tidsskrifter, antologier og konferencer har etableret en såkaldt teknologifilosofi. Selvom Heidegger her måske nok anerkendes som pioner, er det i konfrontationen med hans teknologiforståelse, at denne nye teknologifilosofi fremførers. Men som Riis også skriver, er det sjældent, at Heideggers spredte bemærkninger om teknologi bliver forbundet og tilgået systematisk. Heller ikke teknologifilosoffernes opgør med Heidegger er kendetegnet ved systematik og man finder mange eksempler på forkølede småopgør, placeret i en enkelt fodnote. I forhold hertil adskiller opgøret i Riis' afhandling sig. Afhandlingen er kendetegnet ved en i dansk sammenhæng usædvanlig tekstnær tilgang, der især præger de to forste af afhandlingens $i$ alt tre hoveddele. Første del beskæftiger sig især med Sporgsmalet om teknik- ken (1953); anden del med Kunstvarkets oprindelse (1936). Grundet manglen på systematik i teknologifilosofiens Heidegger-reception er denne akademiske grundighed i sig selv et væsentligt forskningsbidrag. Riis’ eksegese bliver dog aldrig så stringent, at der ikke også er god plads til originale fortolkninger, der baner vejen for det i titlen varslede opgør, som især udspilles $i$ afhandlingens tredje og sidste hoveddel.

Med en fortolkningsramme, hvis vigtigste fikspunkter er Aristoteles' begreb om physis, Nietzsches nihilisme og Ernst Jüngers idé om teknologiens totale mobilisering af mennesker i en art formålsløs evighedsmaskine, fortolker Riis $\mathrm{i}$ afhandlingens forste del den moderne tekniks væsen (som Heidegger kalder stilladset) som den totale mobilisering af alt værende (Die totale Mobilmachung des Seienden). Grebet er som følger: Heideggers væsensbegreb fortolkes som værende analogt til Aristoteles' begreb om physis, altså som en konstant tilbliven, vorden eller bevægelse; via Jünger og Nietzsche beskrives denne bevægelse som en nihilistisk mobilisering af alt værende, herunder mennesker, som manipulerbare, bestillingsklare ressourcer. Når alt værende afdækkes som sådanne, er mobiliseringen fuldført; stilladsets totale herredømme er trådt i kraft 
og forhindrer alle andre udlægninger af det værende.

I afhandlingens anden del beskriver Riis i en omfattende analyse af Kunstvarkets oprindelse, hvordan Heideggers begreb om oprindelse eller udspring (Ursprung) - i mange henseender er synonymt med hans begreb om vasen. Ved kunstværkets udspring fastsættes således en bestemt målestok for - eller sandhed om - det værende, hvilket jo også kendetegner stilladset (den moderne tekniks væsen). Hermed gives begrebet væsen endnu en tidslig dimension, og det bliver følgelig relevant at spørge til stilladsets historiske udspring.

I det meste af afhandlingens tredje og sidste del tilnærmes dette spørgsmål via en genealogisk kritik, der opregner fire mulige udspring til stilladset, der mere eller mindre eksplicit kan læses ud af teknikforedraget. Den forste genealogi fastsætter stilladsets udspring ved de videnskabelige og industrielle revolutioner mellem 1600- og 1800-tallet. Heidegger selv kredser eksplicit om dette udspring i foredraget, som altså synkroniserer stilladsets og det modernes udspring. Dette implicerer imidlertid, at den moderne tekniks væsen i sig selv betragtes som moderne og som sådan adskiller sig fra den antikke tekniks væsen (techné), der ikke udfordrer, men efterligner naturens egen fremstillingsmåde. Hertil påpeger Riis, at udfordringen af naturen og udvindingen af dens energi ikke nødvendigvis hænger sammen med udviklingen af fx strømgeneratorer. Også den antikke tekniks væsen udfordrer, transformerer og bestiller naturen og mennesket. Eksempelvis har matematikken overhovedet muliggjort større byggearbejder, som $\mathrm{fx}$ tempelkonstruktion, ved at have gjort naturen beregnelig, ligesom slaver har været bestilt og mobiliseret i en større maskinel funktionssammenhæng til at opføre templer og andre byggerier. Selv flodens vandkraft er blevet udvundet og således afdækket af den antikke vandmølle med henblik på at male korn til oplagring og bestilling. Dette peger i retning af, at den moderne tekniks vasen må adskilles fra den moderne teknik, og at dens udspring skal søges et andet sted. I antikken for eksempel, som den anden genealogi foreslår!

I anden genealogi fores stilladset tilbage til førsokratikeren Anaximander, da det som bekendt netop er mellem denne og Nietzsche, at Heidegger lader metafysikkens forfaldshistorie udspille sig. I denne optik hænger Heideggers beskyldninger om filosofiens 2500 år lange værensglemsel og det manglende blik for den ontologiske 
differens altså sammen med stilladset. Imidlertid problematiserer den tredje genealogi, som Riis opregner, også dette udspring.

I den tredje genealogi sammenlignes således beskrivelserne af varetagelsens varensart i Heideggers hovedværk Varen og Tid fra 1927 med beskrivelserne af stilladset fra teknik-foredraget fra 1953. Varetagelsen, der er et af de mest basale eksistentialer, som Heidegger opregner ved tilstedevaren (Dasein), er således kendetegnet ved det samme transformerende og udfordrende træk, der også kendetegner den moderne tekniks væsen - stilladset - i Sporgsmålet om teknikken. I Varen og tid beskriver Heidegger således, hvordan skoven, bjerget og floden via varetagelsen af det vedhåndenværende brugstøj først og fremmest åbenbarer sig for tilstedeværen som henholdsvis hugst, stenbrud og vandkraft. I Sporgsmålet om teknikken afdækkes naturen igennem stilladset ligeledes som sådanne disponible ressourcer, der kan bestilles til dette eller hint formål. Men mens denne afdækning af naturen i V aren og tid altså bestemmes som et fundamentalt træk, gøres den i Sporgsmalet om teknikken til et særligt moderne træk. På baggrund af disse udredninger fastsætter den tredje genealogi altså stilladsets udspring samtidigt med menneskets udspring. Med andre ord hører historien om mennesket altså sammen med historien om den moderne tekniks væsen.

Den fjerde og sidste genealogi er også den mest radikale. Her fortolkes stilladsets tekniske mobilisering af alt værende som en på én gang teleologisk og cirkulær stræben hen imod foreningen med naturens forbilledlige fremstillingsmåde. Forfaldshistorien, der hele tiden lurer i teknikforedraget (jf. anden genealogi), transformeres i denne genealogi altså til et naturens triumftog, der bringer stilladsets udspring og afslutning nær hinanden. Denne fortolkning er mulig, dersom kulminationen på stilladsets herredømme forstås som bioteknologi. Ikke blot efterligner bioteknologien naturen og dens fremtræden ud fra sig selv, den eliminerer og udbedrer også naturens fejl og mangler. Kort sagt: "I bioteknologien slår teknologien om i natur", som Riis skriver. I denne genealogi, der modsat de andre tre antyder en cirkulær historieopfattelse, er den antikke tekniks væsen således blot en art mellemstation på vejen mod bioteknologiens totale udviskning af grænserne mellem natur og teknologi. Forfald eller triumf? Bedøm selv.

$\mathrm{Nu}$ er det ingenlunde Riis' hensigt at udpege en af disse fire 
genealogier som den 'rigtige' og således lukke og besvare 'spørgsmålet om teknikken'. Derimod afslører de forskellige genealogier en række spændinger og perspektiver i Heideggers snart 60 år gamle spørgsmål, der kun gør det mere relevant at fortsætte tænkningens nødvendige vovestykke og primære metode: At vedblive at spørge. Over afhandlingens sidste tredive sider anlægger Riis således en spørgende og på én gang ironisk og pietetsfuld egentligheds-jargon, der fortolker stilladset som et tidsligt kunstværk. Hermed knyttes genealogikritikken tæt sammen med afhandlingens to første dele.

Kort fortalt drejer det sig om, at uagtet hvilken værensudlægning der er tale om (en religiøs, metafysisk eller en teknisk/videnskabelig), og uagtet hvad der stifter denne (et kunstværk, en teknologi, et filosofisk system eller en begivenhed), har den en begyndelse og en ende; den er epokal og indeholder heideggersk formuleret både en fare og en redning. Dette begrebspar karakteriserer altså ikke kun stilladset, men er universelt for enhver epokal værensudlægning. Epoker er 'farlige' i den forstand, at de spærrer for alternative forståelser af det værende og 'reddende', fordi de med deres inddeling af historien giver tidens formålsløse og evige bevæ- gelse karakter og identitet. Dermed skabes et forståelsesgrundlag og en fortolkningshorisont for det altid allerede i-verden-værende menneske. Endvidere kan enhver ny begyndelse - ethvert nyt udspring - kun opstå som et opgør med en stabil og totalitær værensudlægning. Men hvis mennesket kun orienterer sig efter det, som er afsløret af den pågældende værensudlægning (stilladser, universelt forstået), så bliver det ubevidst styret af denne - det bliver bestilt og fastsat af denne og lever således som slave under stilladsets herredømme. Menneskets målestok bliver følgelig den således åbenbarede verdens rigtighed. Placeret sådan, har mennesket ingen sans for stilladsernes væsen, men kun for deres følgevirkninger, der til gengæld kommer til at fremstå som naturlove. Hvad det drejer sig om, er altså at udvikle et vasensblik, med hvilket den pågældende epokale værensudlægnings 'rigtighed' kan relativeres og udfordres. Metaforisk udlagt gælder det altså om at slippe stilladsets tilsyneladende objektive vished i springet ud på de 70.000 favne vand, hvor den spørgende åbenhed hersker. Kun her kan vi skylle den rigtighed af, hvori stilladset har hildet os, og som således lutret ane konturerne af en ny begyndelse.

Som allerede berørt excellerer 
Riis' afhandling i grundighed og systematik, hvilket giver teknologifilosofiens Heidegger-reception en behørig tyngde. Afhandlingen kan derfor med rette karakteriseres, som intet mindre end en prolegomena til enbver fremtidig teknologifilosofi! Foruden at være grundig og systematisk, er afhandlingen også original og desuden udpræget venstreheideggeriansk. Det vil sige: Riis forsvarer ikke Heideggers ufejlbarlighed i et papegøjesnakkende og konserverende 'stilladsbyggeri'. Derimod videreudvikler han i en inspireret videresporgen spørgsmålet om teknikken, som med denne rette behandling ikke synes at kende nogen sidste salgsdato. Det eneste, man mere kunne have ønsket sig, var, at de indsigtsfulde pointer var blevet omsat til en eksemplificeret analytik, hvormed nyere konkrete teknologier kunne analyseres og fortolkes. Men med Riis' forarbejde skulle det ikke være vanskeligt at indfri dette ønske, især ikke hvis afhandlingen blev oversat, så endnu flere kunne lade sig inspirere af dens indsigtsfulde tænkning.
CHRISTIAN B.N. GADE

\section{Forsoning efter kræn- kelser}

Paul Leer-Salvesen: Forsoning, Forlaget Alfa, 2011, 305 sider, 289 kr.

Paul Leer-Salvesen er teolog og professor ved Institut for Teologi og Filosofi ved Universitetet i Agder, Norge. Hans seneste bog, Forsoning, er oversat til dansk af Jesper Stange, som er sognepræst ved Vor Frue Kirke i København. Leer-Salvesen giver selv følgende karakteristik af bogens ærinde: "Det har været et gennemgående spørgsmål, hvad forsoning indebærer: Er det nødvendigt at gengælde for at komme videre eller er bod og opgør en mere tilforladelig vej? Denne bog er et forsvar for sidstnævnte alternativ, for ikke-voldelige løsninger, en ikke-voldelig strafferet og en ikke-voldelig teologi” (s. 292).

Forsoning er et centralt tema i forhold til konfliktløsning, og jeg er overbevist om, at Leer-Salvesens bog vil have bred interesse blandt mennesker, der beskæftiger med konflikter i teori og praksis. I oversætterens forord betones det endvidere, at bogen har relevans for mæglere i konfliktråd. Stange skriver: 'Der findes ingen formelle ud- 